International

Medical Society

http://imedicalsociety.org

\title{
Male Doula, why Not?
}

Maurício Caxias de Souza1, Wilma Dias de Fontes Pereira², Sérgio Ribeiro dos Santos ${ }^{2}$, Ericka Silva Holmes ${ }^{3}$, Waglânia de Mendonça Faustino e Freitas ${ }^{2}$, Rayanne Santos Alves ${ }^{3}$, Ana Lúcia de Medeiros ${ }^{1}$, Leila de Cássia Tavares da Fonseca ${ }^{2}$, Saemmy Grasiely Estrela de Albuquerque1, Maria Bernadete de Sousa Costa², Aurilene Josefa Cartaxo Gomes de Arruda², Eveny Natássia Santos Ferreira da Silva ${ }^{4}$, Natalia Peixoto de Oliveira ${ }^{4}$, Márcio Aurélio Diniz ${ }^{5}$, Fátima Michele Bezerra de Sousa6 ${ }^{6}$ Juliana Barbosa Medeiros ${ }^{7}$

\section{Abstract}

Objective: Report experience of male person on a Doulas-training course, whose historical dominance is female people and the training scenario is unique to this genre.

Methods: Qualitative and descriptive study, reporting the experience in a Training Course for Doulas held in the city of São Paulo, Brazil, in June 2015. The results characterize the course, followed by the experienced living. The analysis was funded by the literature on the subject.

Results: The experience showed that the process of working as doula must be delimited by an understanding beyond sexism and from exploitation for it.

Conclusion: It is noteworthy that care as an archetype should not be associated with the gender division of activities in the ideological process of the rite of passage transcribed in a training course, neither in the care of women.

\section{Keywords}

Doulas; Gender Identity; Pregnancy; Nursing.
1 Nurse. Member of the Study and Research Group on Administration and Informatics in Health (GEPAIE/UFPB). Brazil.

2 Nurse. Professor Doctor. Graduation in Nursing of the UFPB. Health Sciences Center (CCS). Brazil.

3 Nurse. PhD Student of the Graduate Program in Health and Decision Models of UFPB. Brazil.

4 Nurse. Specialist in Obstetric Nursing at the Bahian School of Medicine and Health. Salvador, BA. Brazil.

5 Nurse. Nursing Graduation Teacher. Maurício de Nassau College. João Pessoa, PB. Brazil.

6 Nurse. Maternity Frei Damião. João Pessoa, PB. Brazil.

7 Nurse. Specialist in Chronic Diseases noncommunicable. MSc in Public Health from UEPB. João Pessoa, Brazil.

Contact information:

Maurício Caxias de Souza.

\section{Introduction}

Caregiving has been an event that accompanies the human origin. Initially, it was performed intuitively and then became an object of 
study and professional work. The term 'take care', as a transitive indirect verb, means paying attention, thought and imagination. In its development, the appropriation of different technologies that aim to qualified care and meet the demands of society is fundamental. [1]

In the context of health care, care is the action of caring - preserve, keep, maintain, support, take care; it implies so to help others and promote their well-being. Thus, as an archetype - model - care dates back to the origin of man to the maintenance of life and preservation of the different species.

In order to understand the magnitude of the process of caring-care, stands out non-professional care exercised by women who care for women in special moments of their lives. In this context, in the obstetric setting, stand out the actions of caringcare that uses a light character technology, actions developed by doulas in the care of women during pregnancy, childbirth and postpartum.

Doula is a word of Greek origin meaning "woman who serves the other woman". In obstetric care, this caregiver plays physical and emotional support, such as: encouraging, reassuring and stimulating the empowerment of women; comfort measures and provide guidance on the physiology of labor and care, that are necessary for the experience of humanized delivery. [2]

The doula came to be recognized in the United States in 1976, when Dana Raphael described in detail the experience of a woman, whose labor she observed, also puerperium and breast-feeding of another woman. From 1980 onwards, the doulas have acquired a complex popularity, when women distressed by the high caesarean section rates started to invite them to instruct them in their labor process, labor and postpartum period, supporting their decisions, helping them thus to avoid procedures that could restrain and lead them to unnecessary surgery. [3]

The benefits with the presence of doula are so many during labor, delivery and postpartum period, because they reduce considerably the intervention rates and obstetric complications, and strengthen the mother/son relation and breastfeeding. In 1993, "Mothering the mother", a study in the United States showed that the presence of doula reduced by $50 \%$ cesarean rates; reduced by $25 \%$ the duration of labor and $60 \%$ requests for epidural analgesia; $30 \%$ less use of epidural analgesia and $40 \%$ less forceps delivery and decreased by $40 \%$ in the use of oxytocin. [4]

Some studies showed that this care has brought emotional and psychological benefits for mother/ baby at $4^{\text {th }}$ and $8^{\text {th }}$ weeks after birth, resulting in increase of successful breastfeeding; satisfactory interaction between mother and baby; satisfaction with the birth experience; reducing the incidence of postpartum depression and decreased in states of anxiety and low self-esteem. [5, 6]

The World Health Organization (WHO) states that doulas' care goes beyond the care provided to women, translating into decreased of births of babies with Apgar scores below 07 and less unnecessary surgical procedures (C-sections). [7]

According to the North American Doulas Association (DONA), the doula is a trained and experienced professional on providing support, with the ability to provide continuous physical, emotional and even informative support during labor and birth by training by DONA, which reports an exponential growth of conferred certificates, from 31 in 1994 to 2,639 in 2009. In addition, the number of members increased from 750 to 6,994 during the same period, which demonstrates the existence of the labor market and the appreciation of their role in assistance to parturient while early and lightweight technology. [8]

In this sense, the Ministry of Health has implemented policies to encourage natural birth, the presence of the companion, the adaptation to the hospital environment and the continuity of care of the mother throughout the experience of childbirth, with the prospect that various agents ensure full 
care. Indeed, the woman could choose a professional, companion or a family member, friend, midwives, nurses and, they are added to the doulas, to give support during labor and childbirth. [9]

According to the Brazilian Classification of Occupation (CBO), the activity is recorded by paragraph n. 3221-35 and refers to the occupation of professional activities of doula. This insertion in that classification occurred by the Ministry of Labour (MT), after the $8^{\text {th }}$ National Meeting of Doulas, which happened along with the III International Conference on Humanization of Labor and Birth, in 2010. [10]

Before delivery, the doula guides the couple about what to expect from childbirth and postpartum. She/he explains common procedures and helps the woman to prepare, physically and emotionally, for childbirth. During the birth, doula acts as an interface between the service team and the couple. Explaining the complicated medical terms, hospital procedures and mitigating the potential coldness of the service team in one of the most vulnerable moments of mother's life. [11, 12]

In this context, she/he helps the mother to find more comfortable positions for labor and birth, showing efficient ways of breathing and proposing natural measures that can relieve pain, such as baths, massages, relaxation and, when holding the hand of the mother, offering not only trust but also care. [13]

It is important to note that doula does not perform any medical procedure, does not do examinations and does not take care for the newborn health. Not replacing any of the professionals traditionally involved in delivery care. But coming to add up in the actions, and not reduce the assignments. Discussing procedures with staff or questioning decisions is not their function. The real doula is there to empower the woman at the scene of childbirth and encourage her will and conscious choices, based on good scientific evidence.

The doula can develop six types of support: I. Physical - It includes breathing, positioning, hiking, hot or cold compresses and body movements techniques; II. Social - relates to the respect for the family and the multidisciplinary team, favoring a peaceful environment, keeping the focus and interest in parturient; III. Emotional - diminishes the fear, anxiety and promotes encouragement enhancing positive attitudes and behavior; IV. Information - providing guidance and asking questions about obstetrical interventions based on the best available scientific evidence; $V$. Decision Support accepts questions, talking about the choices and responding promptly and objectivity; VI. Alternative and Complementary Practices - promotes integral practices to woman for her comfort, provided that they are trained and qualified to do so (acupuncture, use of devices such as ball, horse), promotes physical and mental relaxation, offers teas medicinal herbs, homeopathy, music therapy, color therapy, hydrotherapy, meditation, prayer and benediction. [11]

In Brazil, there are courses for the training of doulas, both professional and volunteers. Entities such as "Support Group to Maternity Activates of the State of São Paulo (GAMA)" and "National Association of Doulas (ANDO)" are examples of sites that certify people interested in the subject, capable of operating in different modes and exercise volunteer monitoring in any service, or be contracted by women who wish to receive this support. [11]

Thus, in order to contribute to the expansion of the concept of doula, as well as operations in the obstetric scenario which includes care protagonists subjects, regardless of sex or gender, this study aims to describe an experience in a Doula Training Course of the State of São Paulo, while male doula.

\section{Methods}

This is a qualitative and descriptive study, of experience report type, about an experience as male subject in a Training Course of Doulas held in the city of São Paulo, SP, Brazil, in June 2015 period. 
In order to unveil this unique experience, it was decided to describe it, in the results, initially in dimensions that characterize the course, then the experience as the subject of this process. The analysis was funded by scientific literature on the subject.

The objective is to overcome activism and routine repetition of certain procedures, a loss of perspective in relation to the direction of the mentioned practice. To that extent, it becomes an excellent tool to reshape care interventions. [14]

\section{Results}

The Doulas Training Course occurred in the city of São Paulo, and it was carried out in 04 consecutive days, in three shifts, totaling 32 hours. In the course, the search for volunteer and experiential activities, and other sources of knowledge, was proposed to the participants, for the purposes of exercising questioning during the training.

This was a theoretical and practical course, systematized in dialogued exhibitions, associated with the practical skills demonstrations. The group of teachers emphasized the importance of natural childbirth, the problem of unnecessary cesarean sections and issues relating to excessive medicalization of childbirth and birth. The training model believes and strengthens, throughout the course, the natural childbirth, with the fewest possible interventions as the best option for almost all women.

The theoretical bases defined by the team of professionals involved: birth care; obstetrics in Brazil; birth culture in Brazil; anatomy and physiology of childbirth; non-invasive correction of dystocia; WHO recommendations; environment, monitoring, attention to the ideals of birth; activities and functions of the doula; birth plan; pelvic anatomy and the physiological consequences of different positions to give birth; breathing, relaxation, visualization: types and techniques; approach to labor pain; different positions in labor and delivery, dribbling hospital restrictions; newborn reception after childbirth and breastfeeding; massage types and techniques; breast-feeding; dealing with losses.

The vision outlined during the course of what the profession of doula is, which is it to be a doula, history and current situation; the weapons of doula, the words, look, hands, material. It was also discussed how to manage the new profession: schedules, children, duty, contract; doula's ethics; what is her/ his role in the team that assists the woman in labor; how to behave in the delivery room, operating room and obstetrical surgeries.

The course's instrumentalization team, of multidisciplinary character, was composed of experienced teachers in the doula requirement. Among the professional categories: nurses, midwives and psychologists. All knowledge built during the course was based on the recommendations of the World Health Organization, on Evidence-Based Medicine and has the recognition of the Ministry of Health of Brazil.

The course was accomplished in a context of possibilities of care-caring of strong emotions, but also in a construction of fundamental knowledge for care at birth scenario, by actually instrumenting the professional for the exercise of this occupation.

\section{Discussion}

This report was accomplished in a scenario, reflecting not always pain and suffering, but marking a rite of passage, delivery. Therefore, emotions, laughter and tears are the uniqueness of this event. However, given the methodological path selected, plenty of feelings experienced in this report required adjustments.

The provocation "Male doula, why not?" encircles the sociocultural vestiges of an extremely maledominated society, which historically exclude male subjects with the role of caring for someone in certain scenarios, since women, in most societies, have always assumed this function. [15] 
Being a doula, in fact, particularly in Northeastern Brazil, means exploring the possibilities and demystifying taboos. Many of which historically built and entrenched in our society. Thus, it is important to reflect that to participate actively in the process of taking care-caring, in this context, is independent of sex or gender, as the protagonist of this scenario is the woman in the care of the professional she choose for. Thus, the male doulas can also develop fundamental skills for skilled care to the woman in the gravid-puerperal cycle. [10]

Thus, in this scenario, who cares is the one who cares for, and who needs care will be taken care of. [12] Thus, independent of sex or gender of the caregiver subject. But they are directly linked to their skills, i.e., the good practices for the care-caring process. [10]

In this perspective of care, being male doula means being the one who manipulates the woman giving physical and emotional support before, during and after delivery. Thus, the term "doulo" can be understood as a neologism applied to men who instrumentalize women in this singular moment, breaking gender paradigms under care in obstetrics.

\section{Conclusion}

The experience of a male subject was reported, on the participation of a doula-training course. The description of this experience covered aspects of indescribable emotion dividers while doulo in a scenario marked historically by femininity.

The expanded understanding, arising with the participation in the course which instrumentalized the doula process reaffirms, on the one hand, that the construction of gender is closely related to the social inclusion of the subject and, secondly, that it demarcates that care should be independent of sex and gender. Therefore, its operative expression cannot be seen in a relationship of sexist division.
It is expected that from the description of this experience, a pioneer one in the State of Paraiba, new studies and research emerge, enabling overcome the barriers that permeate the process of the doula's work affected by professional in a perception that goes beyond sex and gender.

\section{References}

1. Waldow VR, Borges RF. Cuidar e humanizar: relações e significados. Acta paul. enferm. [Internet]. 2011 [cited 2016 Sep 12]; 24(3):414-418. Available from: http:// www.scielo.br/scielo.php?script=sci arttext\&pid=S010321002011000300017\&lng=en

2. Mafetoni RR, Shimo AKK. Métodos não farmacológicos para alívio da dor no trabalho de parto: revisão integrativa. Rev Min Enferm. [Internet]. 2014 [cited 2016 Sep 12]; 18(2):505-512. Available from: http://www.reme.org.br/artigo/detalhes/942.

3. Klaus M, Kennel J, Berkowitz G, Klaus P. Maternal assistance and support in labor: father, nurse, midwife, or doula. Clinical Consultations in Obstetrices and Gynecology. 1992; 4(4):211217.

4. Klaus M, Kennel J. Mothering the mother: how a doula can help you to have a shorter, easier and healthier birth. Hardcover. 1993.

5. Sosa R, Kennel JH, Klaus MH, Roberteson S, Urrutia J. The effects of a supportive companion on perinatal problems, length of labor, and mother-infant interaction. N Engl J Med. 1980; 303:597-600.

6. Wolman WL, Chalmers B, Hofmeyr J, Nikodem VC. Postpartum depression and companionship in the clinical birth envoirment: a randomized, controlled study. Am J Obstet Gynecol. 1993; 168:1388-1393.

7. Organização Mundial da Saúde. Maternidade segura. Assistência ao parto normal: um guia prático. Genebra (SUI): OMS; 1996.

8. Doulas of North America. [site da internet] 2010; [acessado 2016 jun 11]. Disponível em: <http://www.dona.org>.

9. Santos DS, Nunes IM. Doulas na Assistência ao Parto: Concepção de Profissionais de Enfermagem. Esc Anna Nery Rev Enfermagem [Internet]. 2009 [cited 2016 Sep 12]; 13(3):582589. Available from: http://www.scielo.br/scielo.php?script=sci arttext\&pid=S1414-81452009000300018\&lng=pt.

10. Rede pela Humanização do Parto e do Nascimento. REHUMA. [site da internet] 2015; [acessado em 2016 jun 11]. Disponível em: <http://www.rehuna.org.br/index.php/32-doulas-no-cbo>. 
11. Silva RM, Barros NF, Jorge HMF, MLPT, Ferreira JAR. Evidências qualitativas sobre o acompanhamento por doulas no trabalho de parto e no parto. Ciênc. saúde coletiva. 2012; 17(10):27832794.

12. Souza KRF, Dias MD. História oral: a experiência das doulas no cuidado à mulher. Acta paul. Enferm. 2010; 23(4):493-499.

13. Grupo de Apoio à Maternidade Ativa - GAMA. Curso de formação de doulas. São Paulo: Grupo de Apoio à Maternidade Ativa; 2006.

14. Holliday OJ. Para sistematizar experiências. Editora da UFPB. 1996.

15. Cardoso L, Galera SAF, Vieira MV. O cuidador e a sobrecarga do cuidado à saúde de pacientes egressos de internação psiquiátrica. Acta paul. enferm. [Internet]. 2012 [citado 2016 Set 12]; 25(4):517523. Available from: http://www.scielo.br/scielo.php?script=sci arttext\&pid=S0103-21002012000400006\&lng=pt.

Publish in International Archives of Medicine

International Archives of Medicine is an open access journal publishing articles encompassing all aspects of medical science and clinical practice. IAM is considered a megajournal with independent sections on all areas of medicine. IAM is a really international journal with authors and board members from all around the world. The journal is widely indexed and classified Q2 in category Medicine. 